\title{
Evaluation Framework for Strategic Implementation Process in Large Enterprises
}

\author{
Xiaofeng Zhang*, Haixu Song, Guowei Gao, Li Ma \\ Dept. of Corporate Strategy \\ State Grid Energy Research Institute \\ Beijing, China \\ sgerizxf@163.com
}

\author{
Tuo Liu \\ Research Office \\ State Grid Corporation of China \\ Beijing, China
}

\author{
Longzhu Liu \\ Research Department \\ State Grid Energy Research Institute \\ Beijing, China
}

\begin{abstract}
In recent years, corporate strategic implementation evaluation has received more and more attention from academic circles. Taking relevant theoretical works as a whole, this paper analyzes the characteristics and key elements of the strategic implementation process. In addition, this paper proposes an evaluation framework for the strategic implementation process, which will provide reference for the evaluation of strategic implementation processes in large corporations.
\end{abstract}

Keywords-Corporate strategy; Strategic implementation process; Evaluation framework

\section{INTRODUCTION}

Corporate strategy decisions and analysis have a long-term impact. Maintaining scientific rigor and perspective of the strategy are inevitable requirements for building a century-old corporation. At present, scholars and practitioners have fully recognized the importance of strategic analysis. However, academic research has mainly focused on strategic environmental analysis and strategic performance evaluation. These elements are rarely studied in strategic implementation process evaluation. Strategic execution is the implementation of a strategic objective to achieve corporate's strategic goals. After clarifying their strategic goals, corporations must focus on how to convert their goals into actual behavior and ensure effective implementation. The strategic implementation process is important guarantee for strategy realization. In recent years, strategic implementation process has attracted extensive attention of academic and practical circles committed to strategic management. Based on sorting out the relevant theoretical research of strategic implementation process, this study analyzes the characteristics and key elements of strategic implementation process, and proposes an evaluation framework for the strategic execution process in large corporations.

\section{LITERATURE REVIEW}

The existing works discuss and describe the connotation, elements and analysis models of strategic implementation. The core elements of strategic implementation process are shown in Table I[1-7].

Combining the relevant theories of strategic implementation, we find that strategic execution is an important part of strategic management and important guarantee for strategic realization. The characteristics of strategic execution can be summarized from the following three aspects.

Firstly, strategic implementation is the process of transforming strategy into operational action through management means. The strategy is often a macroscopic description which is thoughtful, directional, principled and strategic without involving how to act at micro level. Torealize the strategy, strategic implementation unpacks and implements strategy layer by layer, creating actionable and achievable steps through resource management, process management, organization management and personnel management.

Secondly, strategic implementation requires consensus, joint participation and effective coordination of all members of the corporation. From the perspective of strategic management process, strategic analysis and strategy formulation are mainly considered by decision makers of corporation, while strategic implementation involves managers and all members of the corporation. Every strategic task requires the participation and cooperation of employees from different departments and levels. Therefore, consensus needs to be formed about strategy across the corporation so that employees can fully understand, recognize and implement the strategy. Moreover, the purpose of strategy is not to maximize the performance of a certain business or a certain department, but to maximize the overall performance of the corporation. For this reason it is even more necessary to coordinate and cooperate among employees.

Thirdly, strategic implementation requires protections such as organizations and systems. Similar to other management processes, strategic implementation also requires protections such as organization, professionals, incentives, management systems, which are to organize, plan, control and supervise strategic implementation. 
TABLE I. CORE ELEMENTS OF STRATEGIC IMPLEMENTATION PROCESS

\begin{tabular}{|c|c|c|}
\hline Dimensions & Sources & Core Elements \\
\hline \multirow{3}{*}{$\begin{array}{l}\text { Connotation } \\
\text { analysis }\end{array}$} & $\begin{array}{l}\text { Larry \& Ram } \\
(2002)\end{array}$ & $\begin{array}{l}\text { Environmental } \\
\text { organizational assumptions, } \\
\text { assessment, method rapacity } \\
\text { discussion, staff coordination, } \\
\text { rewards, etc. }\end{array}$ \\
\hline & $\begin{array}{l}\text { Gerry \& Kevan } \\
(2004)\end{array}$ & $\begin{array}{l}\text { Organization, } \\
\text { processes, resource management }\end{array}$ \\
\hline & $\begin{array}{l}\text { Chen \& Lan } \\
(2011)\end{array}$ & $\begin{array}{l}\text { Implementation plan, resource } \\
\text { allocation, resource control }\end{array}$ \\
\hline \multirow{3}{*}{$\begin{array}{l}\text { Elements } \\
\text { analysis }\end{array}$} & $\begin{array}{l}\text { Okumus } \\
(2001)\end{array}$ & $\begin{array}{l}\text { Environment, organizational } \\
\text { structure, organizational culture, } \\
\text { resource } \\
\text { communication, allocation, } \\
\text { development, } \\
\begin{array}{l}\text { strategy } \\
\text { and control feedback }\end{array}\end{array}$ \\
\hline & $\begin{array}{l}\text { Xue et al. } \\
(2005)\end{array}$ & $\begin{array}{l}\text { Consensus: refers to high-level } \\
\text { consensus, employee consensus } \\
\text { and external consensus, including } \\
\text { strategy formulation, strategy } \\
\text { clarification, and strategic } \\
\text { communication } \\
\text { Collaboration: refers to operational } \\
\text { coordination and organizational } \\
\text { coordination, including index } \\
\text { decomposition, planning, resource } \\
\text { allocation and strategic actions } \\
\text { Control: refers to information } \\
\text { control and behavior control, } \\
\text { including performance assessment, } \\
\text { reward and punishment incentives, } \\
\text { learning adjustment }\end{array}$ \\
\hline & $\begin{array}{l}\text { Wang } \\
(2015)\end{array}$ & $\begin{array}{l}\text { Strategic communication, goal } \\
\text { decomposition, planning, resource } \\
\text { allocation, strategy } \\
\text { implementation, performance } \\
\text { incentives, evaluation feedback }\end{array}$ \\
\hline \multirow{3}{*}{$\begin{array}{l}\text { Analysis } \\
\text { model }\end{array}$} & $\begin{array}{l}\text { McKinsey 7S } \\
\text { Model }\end{array}$ & $\begin{array}{l}\text { Structure, systems, style, staff, } \\
\text { skills, strategy, shared values }\end{array}$ \\
\hline & $\begin{array}{l}\text { Balanced Score } \\
\text { Card(BSC) }\end{array}$ & $\begin{array}{l}\text { Finance, customers, internal } \\
\text { processes, learning and innovation }\end{array}$ \\
\hline & $\begin{array}{l}\text { Management } \\
\text { Control } \\
\text { System(MSC) }\end{array}$ & $\begin{array}{l}\text { Control functions: efficient } \\
\text { processes, increased efficiency } \\
\text { Exploring functions: flexible } \\
\text { learning, environment adapting }\end{array}$ \\
\hline
\end{tabular}

\section{StRategic IMPLEMENTATION PROCESS ANALysiS FRAMEWORK}

The strategic implementation process is mainly supported by three aspects: organizational guarantee, mechanism guarantee and strategic publicity (see Fig. 1). Among them, organizational guarantee is the basis for strategic implementation and is fundamental to promote strategic management in an orderly manner. Mechanism guarantee is the key means of ensuring the corporation's strategy is effectively implemented at all levels. Strategic publicity is the premise of strategic implementation and runs through all aspects of the corporation.

Organizational guarantee. The strategic organization guarantee mainly refers to the leadership's emphasis on strategy, strategic organization setting and departmental synergy. The strategy is formulated by the corporation's senior leadership, and a global arrangement for the corporation that reflects the ideas or intentions of the decision makers. The strategic implementation must first be highly valued and actively promoted by the leadership. At the same time, strategic management also requires a dedicated organization or management team to conduct strategic environmental analysis, major strategic issues research and strategic execution tracking. In addition, strategic implementation requires the participation of all departments and units of the corporation.Synergy between departments is also key factor to evaluate strategic implementation.

Mechanism guarantee. The strategic implementation process is a process of refining, unpacking and realizing strategic objectives and tasks, which needs a certain task breakdown mechanism to promote the strategy from macroscopic direction to micro-practices such as specific tasks or plans. Meanwhile, relevant assessment, incentive mechanisms and strategic management systems should be set up to promote the corporation's strategic landing.

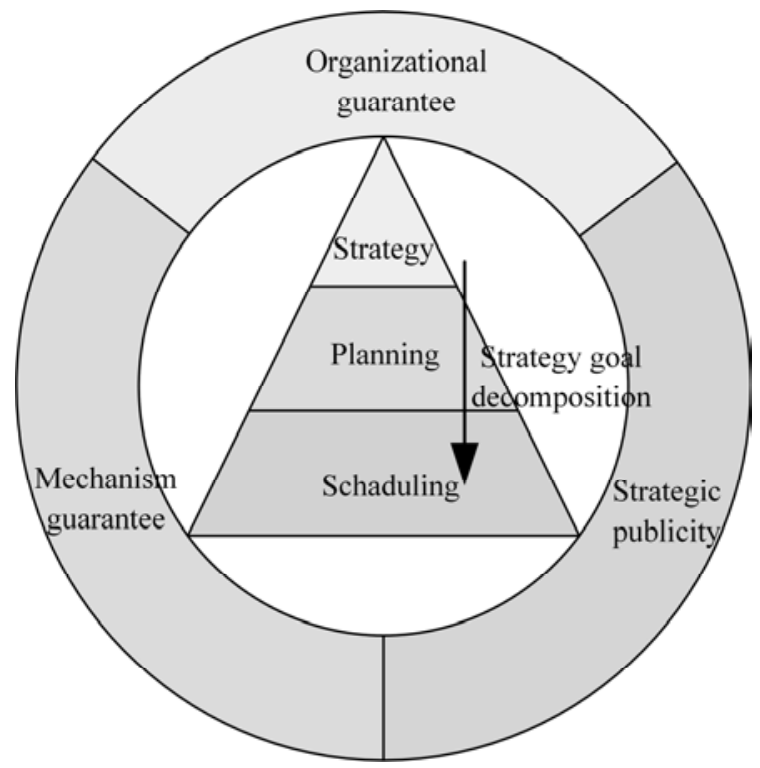

Fig. 1. Strategic implementation analysis framework.

Strategic publicity. Strategic publicity mainly refers to the degree of the corporation's training and promotion of the strategy, as well as all employees' understanding and recognition of the strategy which include connotation, vision, goals and priorities. At the headquarters level, the development strategy outline is regularly released to promote the formation of strategic consensus and promote the strategic landing. Through the convening of annual and quarterly work meetings to elaborate strategic thinking, the overall corporation will profoundly understand the strategic thinking of the company and condense the synergy of development.

Through the above analysis, the evaluation of strategic implementation process is mostly qualitative analysis. In this paper, we propose a quantitative assessment model to evaluate strategic implementation process. In this model, a certain number of experts who have a deep understanding of the enterprise are selected, and they carry out the weight setting and comprehensive evaluation of each strategic implementation element based on the Likert table (see Table II). 
TABLE II.

QUANTITATIVE ASSESSMENT BASIS FOR THE STRATEGIC IMPLEMENTATION PROCESS

\begin{tabular}{|c|c|c|c|c|c|}
\hline \multirow{2}{*}{$\begin{array}{c}\text { Strategic } \\
\text { Implementation } \\
\text { Elements } \\
\end{array}$} & \multicolumn{5}{|c|}{ Assignment } \\
\hline & 1 & 2 & 3 & 4 & 5 \\
\hline $\begin{array}{l}\text { Organizational } \\
\text { guarantee }\end{array}$ & $\begin{array}{l}\text { Leaders do not pay } \\
\text { attention to } \\
\text { strategy, without } \\
\text { special strategy } \\
\text { committee in the } \\
\text { board of directors, } \\
\text { no strategic } \\
\text { management staff, } \\
\text { communication } \\
\text { between } \\
\text { departments is not } \\
\text { smooth }\end{array}$ & $\begin{array}{l}\text { Leaders attach great } \\
\text { importance to } \\
\text { strategy, with a } \\
\text { special strategy } \\
\text { committee in the } \\
\text { board of directors, no } \\
\text { strategic management } \\
\text { staff }\end{array}$ & $\begin{array}{l}\text { Leaders attach more } \\
\text { importance to the } \\
\text { strategy, with a special } \\
\text { strategy committee in the } \\
\text { board of directors, There } \\
\text { are people who specialize } \\
\text { in full or part-time for } \\
\text { strategic management, } \\
\text { communication between } \\
\text { departments is relatively } \\
\text { smooth }\end{array}$ & $\begin{array}{l}\text { Leaders attach great } \\
\text { importance to the } \\
\text { strategy, with a special } \\
\text { strategy committee in the } \\
\text { board of directors, there } \\
\text { are professionals } \\
\text { engaged in strategic } \\
\text { management, } \\
\text { communication between } \\
\text { departments is smooth }\end{array}$ & $\begin{array}{l}\text { Leaders attach great } \\
\text { importance to the } \\
\text { strategy, with a } \\
\text { special strategy } \\
\text { committee in the } \\
\text { board of directors, } \\
\text { there are a special } \\
\text { strategic management } \\
\text { working group, } \\
\text { communication } \\
\text { between departments } \\
\text { is very smooth }\end{array}$ \\
\hline $\begin{array}{l}\text { Mechanism } \\
\text { guarantee }\end{array}$ & $\begin{array}{l}\text { No task } \\
\text { decomposition, no } \\
\text { strategic } \\
\text { management } \\
\text { system, rewards \& } \\
\text { punishments and } \\
\text { incentives }\end{array}$ & $\begin{array}{l}\text { The task } \\
\text { decomposition was } \\
\text { realized, but was not } \\
\text { established strictly in } \\
\text { accordance with the } \\
\text { layer of strategy- } \\
\text { planning-scheduling, } \\
\text { reward \& punishment } \\
\text { and incentive } \\
\text { mechanisms have not } \\
\text { yet been formed }\end{array}$ & $\begin{array}{l}\text { Task can be decomposed } \\
\text { according to layer of } \\
\text { strategy-planning- } \\
\text { scheduling, and is } \\
\text { basically reasonable. A } \\
\text { basically perfect reward \& } \\
\text { punishment mechanism, } \\
\text { incentive mechanism and } \\
\text { management system are } \\
\text { established for the } \\
\text { strategic landing }\end{array}$ & $\begin{array}{l}\text { Task can be decomposed } \\
\text { according to layer of } \\
\text { strategy-planning- } \\
\text { scheduling, and is } \\
\text { reasonable. A relatively } \\
\text { perfect reward \& } \\
\text { punishment mechanism, } \\
\text { incentive mechanism and } \\
\text { management system are } \\
\text { established for the } \\
\text { strategic landing }\end{array}$ & $\begin{array}{l}\text { Task can be } \\
\text { decomposed } \\
\text { according to layer of } \\
\text { strategy-planning- } \\
\text { scheduling, and is } \\
\text { very reasonable. A } \\
\text { very perfect reward \& } \\
\text { punishment and } \\
\text { mechanism, incentive } \\
\text { mechanism system } \\
\text { management for the } \\
\text { are established for } \\
\text { strategic landing }\end{array}$ \\
\hline Strategic publicity & $\begin{array}{l}\text { No training for } \\
\text { strategic managers, } \\
\text { employees do not } \\
\text { recognize } \\
\text { corporation's } \\
\text { strategy }\end{array}$ & $\begin{array}{l}\text { The strategic } \\
\text { managers are trained } \\
\text { every year, but the } \\
\text { training is not } \\
\text { specially held, Only a } \\
\text { small part of the } \\
\text { corporation's strategy } \\
\text { can be recognized by } \\
\text { employees }\end{array}$ & $\begin{array}{l}\text { There is } 1 \text { special training } \\
\text { for strategic managers } \\
\text { each year, employees } \\
\text { basically recognize the } \\
\text { corporation's strategy }\end{array}$ & $\begin{array}{l}\text { There are } 2-3 \text { special } \\
\text { training for strategic } \\
\text { managers each year, } \\
\text { employees can recognize } \\
\text { most of the corporation's } \\
\text { strategy }\end{array}$ & $\begin{array}{l}\text { There are more than } 3 \\
\text { special training for } \\
\text { strategic managers } \\
\text { each year, employees } \\
\text { fully recognize the } \\
\text { corporation's strategy }\end{array}$ \\
\hline
\end{tabular}

\section{CONCLUSIONS}

Based on review of the existing literature, this paper proposes an evaluation and analysisframework for the strategic implementation process of large corporation which includes organizational guarantee, mechanism guarantee and strategic publicity. This paper provides a reference for the strategic process analysis, exploration and mining of the reasons leading to performance of strategic implementation and further strategic optimization and strategic control.

\section{REFERENCES}

[1] Y.K. Xue, D.Q. Qi, and H.N. Wei, "Analysis of the status quo of chinese enterprise strategy implementation and determinants of execution," Management World, vol. 2005(09), pp. 88-98+172.
[2] G.Q. Chen and B.Y. Lan, "Research on Tool System in the Process of Enterprise Strategy Implementation-Based on the Perspective of Resource Allocation," Economic Issues, vol. 2011(02), pp. 72-75.

[3] M.X. Wang, "Analysis of the Linkage between Enterprise Strategy and Operation Management and the Path of Strategic Execution," Management Modernization, vol. 35(01), pp. 49-51, 2015.

[4] Y.L. Li, "Review and Prospect of Strategic Implementation Research," Exploration of Economic Issues, vol. 2013(02), pp. 171-177.

[5] G. Johnson and K. Scholes, Strategic Management. People's Posts and Telecommunications Press, 2004.

[6] B. Larry, Execution: the discipline of getting things done /-1st ed. Crown Business, 2002.

[7] F. Okumus, "Towards a strategy implementation framework," International Journal of Contemporary Hospitality Management, vol. 13(13), pp. 327-338, 2001. 